\title{
Antenatal Care dan Komplikasi Kehamilan di Provinsi Daerah Istimewa Yogyakarta dan Jawa Barat
}

\author{
Antenatal Care and Pregnancy Complications \\ in The Province of The Special Region of Yogyakarta and West Java
}

\author{
Helwiah Umniyati ${ }^{1 凶}$, Telly Purnamasari², Esty Febriani ${ }^{3}$ \\ ${ }^{1}$ Fakultas Kedokteran Gigi Universitas YARSI \\ 2Litbang Kemenkes \\ ${ }^{3}$ Stikes Kuningan
}

\section{ABSTRAK}

Latar Belakang: Rendahnya cakupan antenatal care (ANC) dan tingginya komplikasi kehamilan merupakan faktor risiko penting penyebab kematian ibu di Indonesia. RISKESDAS 2010 memperlihatkan komplikasi kehamilan tertinggi di Provinsi D.I. Yogyakarta (13,9\%), bila dibandingkan angka nasional (6,5\%) dan Jawa Barat (6,9\%).

Tujuan: Untuk mengetahui faktor-faktor yang berhubungan dengan komplikasi kehamilan di Provinsi Daerah Istimewa Yogyakarta dan Jawa Barat.

Metode: Penelitian ini merupakan gabungan dari penelitian kuantitatif dan kualitatif. Penelitian kuantitatif menggunakan data RISKESDAS 2010 sedangkan penelitian kualitatif menggunakan wawancara mendalam dan FGD.

Hasil: Analisis regresi cox menunjukkan bahwa menginformasikan gejala komplikasi kehamilan selama kunjungan ANC berhubungan secara signifikan dengan komplikasi kehamilan. Hasil dari penelitian kualitatif menunjukkan bahwa penerapan ANC di D.I. Yogyakarta sangat baik ketika dibandingkan dengan Jawa Barat. Keberhasilan ini tidak terlepas dari dukungan pemerintah dan masyarakat. Tingginya deteksi dini risiko kehamilan oleh masyarakat $(157,88 \%)$ diduga menjadi penyebab rendahnya AKI di D.I. Yogyakarta.

Kesimpulan: Pelaksanaan program KIA di D.I. Yogyakarta sudah sangat baik. Disarankan bahwabidan selalu menginformasikan risiko kehamilan sejak ANC pertama. Hal ini dapat mencegah terjadinya komplikasi kehamilan, terutama di provinsi dengan angka kematian ibu yang tinggi.

Kata Kunci: Komplikasi kehamilan; ANC; Riskesdas; studi kualitatif

\section{ABSTRACT}

Background: Low ANC coverage and high pregnancy complications are risk factors for MMR in Indonesia. RISKESDAS 2010 showed the highest pregnancy complications in Special Region of Yogyakarta (13.9\%), compared to national (6.5\%) and West Java province (6.9\%).

Objective: To determine factors associated with pregnancy complications in Special Region of Yogyakarta and West Java Provinces.

Methods: This was a mixedresearch. Quantitative research used RISKESDAS 2010 data and qualitative research usedin-depth interviews and FGDs.

Results: Cox regression analysis showed that informing symptoms of pregnancy complications during ANC visits was significantly associated with pregnancy complications. Qualitative research showed that the implementation of ANC in Special Region of Yogyakarta was very good compared to West Java. This success could not be separated from the support of the government and community. High early detection of pregnancy risk by the community (157.88\%) was thought to be the cause of the low MMR in Special Region of Yogyakarta. Conclusion: The implementation of the MCH program in Special Region of Yogyakarta was very good. It is recommended that midwives always inform the risk of pregnancy since the first ANC. This can prevent pregnancy complications, especially in provinces with high MMR.

Keywords: Antenatal care; Pregnancy complications; Riskesdas

๑Corresponding author: helwiah.umniyati@yarsi.ac.id

Diajukan 23 Juli 2021 Diperbaiki 1 Januari 2022 Diterima 1 Januari 2022 
PENDAHULUAN

Angka kematian ibu (AKI) merupakan salah satu parameter derajat kesehatan suatu negara. Secara global masih cukup tinggi, terutama saat proses persalinan. AKI di negara berpenghasilan rendah pada tahun 2017 adalah 462 per 100.000 kelahiran hidup dibandingkan 11 per 100.000 kelahiran hidup di negara berpenghasilan tinggi (WHO, 2019).

Diperkirakan 303.000 perempuan dan remaja putri meninggal komplikasi terkait kehamilan dan persalinan pada tahun 2015 (Alkema et al., 2016). Setiap hari sekitar 810 wanita meninggal selama kehamilan dan setelah persalinan atau sekitar 295.000 wanita meninggal pada 2017 di mana 94\% dari kematian ibu terjadi di negara berkembang terutama di Sub-Sahara Afrika dan Asia Selatan (WHO, 2019).

Kematian ibu di negara berkembang 15 kali lebih tinggi daripada di negara maju. Sebagian besar dari ibu hamil meninggal karena mereka tidak mendapatkan akses ke layanan kesehatan dan perawatan emergency/darurat yang terampil (WHO, 2019).

Angka kematian ibu (AKI) di Indonesia masih tinggi bila dibandingkan dengan AKI di negara-negara ASEAN lainnya. Menurut Survei Demografi Kesehatan Indonesia (SDKI) tahun 2012, angka kematian ibu di Indonesia adalah 359 per 100.000 kelahiran hidup, angka ini naik dari 228 per 100000 kelahiran hidup berdasarkan SDKI tahun 2007 (Kementerian Kesehatan, 2014).

Indonesia sulit untuk mencapai target Sustainable Development Goals (SDGs) menurunkan AKI menjadi 70 per 100.000 kelahiran hidup pada tahun 2030. Hingga tahun 2019, AKI Indonesia masih tetap tinggi, yaitu 305 per 100.000 kelahiran hidup (Susiana S, 2019).

Salah satu faktor yang dianggap merupakan faktor risiko tinggi kematian ibu adalah masih rendahnya cakupan antenatal care (ANC) dan tingginya komplikasi kehamilan. Komplikasi kehamilan dan persalinan lebih tinggi pada remaja perempuan usia 10-19 dibandingkan dengan perempuan usia $20-$ 24 tahun dan risiko kematian paling tinggi pada kehamilan pada remaja usia $10-14$ tahun (WHO, 2019). Walaupun data komplikasi berdasarkan umur tidak ada di Riskesdas, pola yang sama juga terjadi di Indonesia.

Menurut data RISKESDAS 2010, komplikasi kehamilan di Provinsi Jawa Barat lebih rendah dibandingkan dengan Daerah Istimewa Yogyakarta (DIY) yaitu $6.5 \%$ berbanding dengan $13,9 \%$. Namun disisi lain, Provinsi Jawa Barat merupakan provinsi dengan persentase tertinggi menyumbang kematian ibu di Indonesia tahun 2010 di mana 19.8\% kematian ibu berasal dari provinsi tersebut (Kementerian Kesehatan, 2010). Sebaliknya, Provinsi DIY hanya menyumbang $1,1 \%$ kematian ibu di Indonesia karena di Provinsi DIY persentase antenatal care terbaik (Kementerian Kesehatan, 2010).

Sekitar 75\% kematian ibu karena komplikasi, yang penyebabnya adalah perdarahan hebat, infeksi, tekanan darah tinggi selama kehamilan (pre-eklampsia dan eklampsia) dan komplikasi dari persalinan serta aborsi yang tidak aman (Say et al., 2014). Di Indonesia, penyebab utama kematian ibu adalah perdarahan $(30,3 \%)$, eklampsia/hipertensi $(27,1 \%)$, dan infeksi (7,3\%) (Kementerian Kesehatan, 2014). Penelitian ini bertujuan untuk mengetahui faktor-faktor yang berhubungan dengan terjadinya komplikasi kehamilan dengan melakukan analisa lanjut data RISKESDAS 2010 pada Provinsi Jawa Barat dibandingkan dengan Provinsi DIY yang dilengkapi dengan penelitian kualitatif.

\section{METODE PENELITIAN}

Penelitian ini dilaksanakan pada April 2012 sampai dengan November 2012. Studi kuantitatif menggunakan data 
RISKESDAS 2010. Populasi penelitian: seluruh ibu yang memiliki anak berusia $0-$ 59 bulan pada saat data RISKESDAS dikumpulkan. Kriteria inklusi sampel adalah adanya data komplikasi kehamilan. Lokasi penelitian Provinsi Jawa Barat dan Provinsi DIY.

Besar sampel yang akan dipakai dalam analisis: seluruh populasi (total sampling). Jumlah sampel ibu di Jawa Barat adalah 2942, akan tetapi yang dilakukan analisis hanya 2868 karena 74 sampel tidak mempunyai data komplikasi kehamilan, sedangkan Provinsi DIY jumlah sampel ibu sebanyak 247 dan seluruh sampel dilakukan analisis. Data komplikasi kehamilan didapatkan berdasarkan pertanyaan pada ibu apakah mengalami komplikasi kehamilan dengan tidak membedakan jenis komplikasinya.

Faktor risiko kehamilan termasuk data sosio-demografi (pendidikan, pekerjaan, tempat tinggal), faktor ibu (usia ibu saat melahirkan, IMT, jumlah anak, interval melahirkan, kehamilan yang diinginkan), faktor ANC dan layanan kesehatan (Kunjungan ANC, Imunisasi TT, Tablet Fe, tempat pemeriksaan antenatal, tenaga kesehatan yang melakukan antenatal, jarak ke fasilitas kesehatan, serta penjelasan tanda bahaya kehamilan) (Kementerian Kesehatan, 2010). Analisis data chi-square untuk bivariat dan analisis multivariat dengan regresi cox menggunakan program SPSS 24.0.

Studi kualitatifnya dilakukan di Kabupaten Karawang untuk mewakili Provinsi Jawa Barat dan Kota Yogyakarta untuk wakil dari Provinsi DIY. Pada studi kualitatif ini informasi yang banyak digali adalah proses ante natal care (ANC) melalui wawancara mendalam (in depth interview) dan focus group discussion (FGD). Data kualitatif ini akan mendukung bahasan dari hasil data kuantitatif.

FGD dilakukan pada tiga kelompok informan yaitu: kelompok ibu menyusui dengan usia bayi antara 3-6 bulan yang melahirkan dan melakukan ANC di Puskesmas atau BPS, kelompok Ibu hamil dan kelompok Bidan Praktik Swasta (BPS). Selain FGD, dilakukan juga wawancara mendalam pada dua Bidan Puskesmas dan Kepala seksi KIA Dinas Kesehatan. Persetujuan Etikdidapatkan dari Badan Litbangkes Kementerian Kesehatan RI.

\section{HASIL DAN PEMBAHASAN}

Berdasarkan data Riskesdas 2010 terlihat bahwa persentase komplikasi kehamilan di Provinsi DIY lebih tinggi dari pada persentase komplikasi kehamilan di Provinsi Jawa Barat (13,0\% dibandingkan 6,4\%). Bila dilihat angka kematian ibu (AKI), di Provinsi Jawa Barat AKI jauh lebih tinggi bila dibandingkan dengan AKI di Provinsi DIY

Berdasarkan hasil analisis bivariat pada table 1 faktor-faktor yang berhubungan dengan komplikasi kehamilan di Provinsi Jawa Barat adalah IMT, imunisasi TT, keinginan hamil dan diberi tahu tanda bahaya kehamilan ketika ANC. Di Provinsi DIY hanya variabel diberitahu tanda bahaya kehamilan ketika ANC yang berhubungan dengan komplikasi kehamilan.

Tabel 1. Faktor Determinan dengan Komplikasi Kehamilan di Provinsi Jawa Barat dan DIY

\begin{tabular}{|c|c|c|c|c|c|c|c|}
\hline \multirow{2}{*}{ No. } & \multirow{2}{*}{ Faktor Determinan } & \multicolumn{3}{|c|}{$\begin{array}{c}\text { Komplikasi Kehamilan } \\
\text { di Provinsi Jawa Barat }(n=2759)\end{array}$} & \multicolumn{3}{|c|}{$\begin{array}{l}\text { Komplikasi Kehamilan } \\
\text { di Provinsi DIY }(n=247)\end{array}$} \\
\hline & & Komplikasi & $\begin{array}{c}\text { Tidak } \\
\text { Komplikasi }\end{array}$ & $\begin{array}{c}\text { Nilai } \\
\text { p-value }\end{array}$ & Komplikasi & $\begin{array}{c}\text { Tidak } \\
\text { Komplikasi }\end{array}$ & $\begin{array}{c}\text { Nilai } \\
\text { p-value }\end{array}$ \\
\hline 1 & $\begin{array}{l}\text { Daerah } \\
\text { a. Desa } \\
\text { b. Kota }\end{array}$ & $\begin{array}{c}60(5,4) \\
124(7,1)\end{array}$ & $\begin{array}{l}1055(94,6) \\
1629(92,9)\end{array}$ & 0,085 & $\begin{array}{l}19(13,1) \\
13(12,7)\end{array}$ & $\begin{array}{l}126(86,9) \\
89(87,3)\end{array}$ & 0,934 \\
\hline 2 & $\begin{array}{l}\text { Pendidikan Ibu } \\
\text { a. Rendah } \\
\text { b. Tinggi }\end{array}$ & $\begin{array}{l}120(6,0) \\
64(7,5)\end{array}$ & $\begin{array}{l}1895(94,0) \\
789(92,5)\end{array}$ & 0,144 & $\begin{array}{l}15(14,2) \\
17(12,1)\end{array}$ & $\begin{array}{l}91(85,8) \\
124(87,9)\end{array}$ & 0,628 \\
\hline
\end{tabular}


Antenatal Care dan Komplikasi Kehamilan...

Tabel 1. Faktor Determinan dengan Komplikasi Kehamilan di Provinsi Jawa Barat dan DIY (lanjutan...)

\begin{tabular}{|c|c|c|c|c|c|c|c|}
\hline \multirow{2}{*}{ No. } & \multirow{2}{*}{ Faktor Determinan } & \multicolumn{3}{|c|}{$\begin{array}{c}\text { Komplikasi Kehamilan } \\
\text { di Provinsi Jawa Barat }(n=2759)\end{array}$} & \multicolumn{3}{|c|}{$\begin{array}{l}\text { Komplikasi Kehamilan } \\
\text { di Provinsi DIY }(n=247)\end{array}$} \\
\hline & & Komplikasi & $\begin{array}{c}\text { Tidak } \\
\text { Komplikasi }\end{array}$ & $\begin{array}{l}\text { Nilai p- } \\
\text { value }\end{array}$ & Komplikasi & $\begin{array}{c}\text { Tidak } \\
\text { Komplikasi }\end{array}$ & $\begin{array}{l}\text { Nilai p- } \\
\text { value }\end{array}$ \\
\hline 3 & $\begin{array}{l}\text { Pekerjaan Ibu } \\
\text { a. Tidak Bekerja } \\
\text { b. Bekerja }\end{array}$ & $\begin{array}{l}123(6,2) \\
61(7,0)\end{array}$ & $\begin{array}{l}1871(93,8) \\
813(93,0)\end{array}$ & 0,464 & $\begin{array}{l}11(13,8) \\
21(12,6)\end{array}$ & $\begin{array}{c}69(86,3) \\
146(87,4)\end{array}$ & 0,797 \\
\hline 4 & $\begin{array}{l}\text { Umur Ibu } \\
\text { a. }<20 \text { tahun } \\
\text { b. } 20-35 \text { tahun } \\
\text { c. }>35 \text { tahun }\end{array}$ & $\begin{array}{c}7(3,4) \\
147(6,5) \\
30(7,5)\end{array}$ & $\begin{array}{c}196(96,6) \\
2118(93,5) \\
370(92,5)\end{array}$ & 0,151 & $\begin{array}{c}2(15,4) \\
23(11,6) \\
7(20,0)\end{array}$ & $\begin{array}{c}11(84,6) \\
176(88,4) \\
28(80,0)\end{array}$ & 0,377 \\
\hline 5 & $\begin{array}{l}\text { ANC K1 } \\
\text { a. Tidak } \\
\text { b. Ya }\end{array}$ & $\begin{array}{c}26(7) \\
155(6,6)\end{array}$ & $\begin{array}{c}348(93) \\
2185(93,4)\end{array}$ & 0,901 & $\begin{array}{c}4(21,1) \\
26(11,5)\end{array}$ & $\begin{array}{c}15(78,9) \\
200(88,5)\end{array}$ & 0,223 \\
\hline 6 & $\begin{array}{l}\text { K4 pola 1,1,2 } \\
\text { a. Tidak Lengkap } \\
\text { b. Lengkap }\end{array}$ & $\begin{array}{c}35(5,3) \\
146(6,9)\end{array}$ & $\begin{array}{l}622(94,7) \\
1960(93,1)\end{array}$ & 0,173 & $\begin{array}{l}4(16,0) \\
28(12,6)\end{array}$ & $\begin{array}{c}21(84) \\
194(87,4)\end{array}$ & 0,633 \\
\hline 7 & $\begin{array}{l}\text { ANC oleh Nakes } \\
\text { a. Tidak } \\
\text { b. Ya }\end{array}$ & $\begin{array}{l}25(6,1) \\
159(6,5)\end{array}$ & $\begin{array}{l}382(93,9) \\
2302(93,5)\end{array}$ & 0,894 & $\begin{array}{c}2(40,0) \\
30(12,4)\end{array}$ & $\begin{array}{c}3(60, .0) \\
212(87,6)\end{array}$ & 0,069 \\
\hline 8 & $\begin{array}{l}\text { IMT } \\
\text { a. }<18.5 \\
\text { b. } 18.5-23 \\
\text { c. }>23.0\end{array}$ & $\begin{array}{c}16(7,5) \\
62(4,7) \\
106(7,9)\end{array}$ & $\begin{array}{l}197(92,5) \\
1248(95,3) \\
1237(92,1)\end{array}$ & 0,003 & $\begin{array}{c}5(26,3) \\
13(10,8) \\
14(13,0)\end{array}$ & $\begin{array}{c}14(73,3) \\
107(89,2) \\
94(87)\end{array}$ & 0,175 \\
\hline 9 & $\begin{array}{l}\text { Imunisasi TT } \\
\text { a. Tidak } \\
\text { b. Ya }\end{array}$ & $\begin{array}{l}26(4,7) \\
151(7,2)\end{array}$ & $\begin{array}{l}533(95,3) \\
1944(92,8)\end{array}$ & 0,040 & $\begin{array}{l}5(16,1) \\
27(12,7)\end{array}$ & $\begin{array}{c}26(83,9) \\
186(87,3)\end{array}$ & 0,595 \\
\hline 10 & $\begin{array}{l}\text { Minum TTD } \\
\text { a. }<90 \text { tablet } \\
\text { b. } \geq 90 \text { tablet }\end{array}$ & $\begin{array}{c}26(4,7) \\
151(7,2)\end{array}$ & $\begin{array}{l}1900(92,4) \\
423(92,8)\end{array}$ & 0,828 & $\begin{array}{c}6(13,3) \\
25(13,0)\end{array}$ & $\begin{array}{l}39(86,7) \\
168(87,0)\end{array}$ & 0,946 \\
\hline 11 & $\begin{array}{l}\text { Interval kelahiran } \\
\text { a. }<2 \text { Tahun } \\
\text { b. } \geq 2 \text { Tahun } \\
\text { c. Tdk-ada Interval }\end{array}$ & $\begin{array}{c}16(8,0) \\
112(6,7) \\
56(5,6)\end{array}$ & $\begin{array}{c}183(92,0) \\
1564(93,3) \\
937(94,4)\end{array}$ & 0,355 & $\begin{array}{l}2(13,3) \\
15(12,1) \\
15(13,9)\end{array}$ & $\begin{array}{l}13(86,7) \\
109(87,9) \\
93(86,1)\end{array}$ & 0,890 \\
\hline 12 & $\begin{array}{l}\text { Keinginan Hamil } \\
\text { a. Tidak ingin Hamil } \\
\text { b. Ingin Hamil }\end{array}$ & $\begin{array}{l}27(9,8) \\
112(5,4)\end{array}$ & $\begin{array}{c}249(90,2) \\
1957(94,6)\end{array}$ & 0,002 & $\begin{array}{c}1(5) \\
31(13,7)\end{array}$ & $\begin{array}{c}19(95) \\
196(86,3)\end{array}$ & 0,269 \\
\hline 13 & $\begin{array}{l}\text { Paritas } \\
\text { a. } \geq 3 \text { anak } \\
\text { b. }<3 \text { anak }\end{array}$ & $\begin{array}{l}59(6,5) \\
125(6,4)\end{array}$ & $\begin{array}{c}850(93,5) \\
1834(93,6)\end{array}$ & 0,976 & $\begin{array}{l}4(10,0) \\
28(13,5)\end{array}$ & $\begin{array}{c}36(90,0) \\
179(86,5)\end{array}$ & 0,543 \\
\hline 14 & $\begin{array}{l}\text { Diberitahu Tanda } \\
\text { Bahaya Kehamilan } \\
\text { a. Tidak } \\
\text { b. Ya }\end{array}$ & $\begin{array}{c}54(3,5) \\
127(10,5)\end{array}$ & $\begin{array}{l}1499(96,5) \\
1083(89,5)\end{array}$ & 0,000 & $\begin{array}{c}7(6,8) \\
25(17,4)\end{array}$ & $\begin{array}{c}96(93,2) \\
119(82,6)\end{array}$ & 0,015 \\
\hline 15 & $\begin{array}{l}\text { Diberitahu Tanda } \\
\text { Bahaya Kehamilan } \\
\text { a. Tidak } \\
\text { b. Ya }\end{array}$ & $\begin{array}{c}12(4,2) \\
172(6,7)\end{array}$ & $\begin{array}{c}274(95,8) \\
2408(93,3)\end{array}$ & 0,136 & $\begin{array}{c}0(0) \\
32(13,0 \%)\end{array}$ & $\begin{array}{c}20(100) \\
195(85,9)\end{array}$ & 0,072 \\
\hline
\end{tabular}

Tabel 2. Faktor Determinan Komplikasi Kehamilan di Provinsi Jawa Barat

\begin{tabular}{lccc}
\hline \multicolumn{1}{c}{ Variabel } & $\begin{array}{c}\text { Nilai p- } \\
\text { value }\end{array}$ & PR $^{*}$ & $\mathbf{9 5 \%}$ C.I \\
\hline Jumlah Balita & 0,034 & 1,98 & $1,06-3,73$ \\
$\begin{array}{l}\text { Diberitahu Tanda } \\
\text { Bahaya Kehamilan }\end{array}$ & 0,000 & 3,29 & $2,37-4,57$ \\
IMT & 0,023 & 0,96 & $0,93-0,99$ \\
Ingin Hamil & 0,008 & 0,55 & $0,35-0,85$ \\
Konstanta & 0,000 & & \\
*Prevalens ratio & $(\mathrm{n}=2759)$ & menggunakan \\
Regresi Cox & & &
\end{tabular}

Pada Propinsi Jawa Barat hasil multivariat dengan menggunakan regresi Cox didapatkan faktor risiko komplikasi kehamilan adalah jumlah balita, diberitahu tanda bahaya kehamilan, IMT, dan ingin hamil. Ibu yang tidak diberitahu tanda bahaya kehamilan 3,3 kali berisiko mengalami komplikasi kehamilan dibandingkan dengan ibu yang diberitahu tanda bahaya kehamilan. 
Antenatal Care dan Komplikasi Kehamilan...

\begin{tabular}{lccc}
\multicolumn{4}{c}{$\begin{array}{c}\text { Tabel 3. Faktor Determinan Komplikasi } \\
\text { Kehamilan di Provinsi DI Yogyakarta }\end{array}$} \\
\hline \multicolumn{1}{c}{ Variabel } & $\begin{array}{c}\text { Nilai } \\
\text { p-value }\end{array}$ & PR* & 95\% C.I \\
\hline $\begin{array}{l}\text { Diberitahu Tanda } \\
\text { Bahaya Kehamilan (1) } \\
\text { Konstanta }\end{array}$ & 0,018 & 2,88 & $1,20-6,95$ \\
\hline
\end{tabular}

*Prevalens ratio $(\mathrm{n}=247)$ menggunakan Regresi Cox

Pada Propinsi DIY hasil multivariat dengan menggunakan regresi Cox didapatkan ibu yang tidak diberitahu tanda bahaya kehamilan berisiko 2,9 kali mengalami komplikasi kehamilan dibandingkan dengan ibu yang diberitahu tanda bahaya kehamilan.

Cakupan K1 pada Provinsi Jawa Barat mengalami kenaikan dari 75,5\% Riskesdas 2010 menjadi 88,7\% Riskesdas 2018, akan tetapi masih lebih rendah dari cakupan K1 pada Provinsi DIY yaitu 91,5\% Riskesdas 2010 dan 94,4\% Riskesdas 2018 (Kementerian Kesehatan, 2010; Kementerian Kesehatan, 2019). Berdasarkan wawancara dengan Kasie Kesga Kabupaten Karawang, dijelaskan juga bahwa target kunjungan K1 tahun 2012 72\% masih banyak yang belum tercapai, dengan rentang capaian antara $54,1 \%-77 \%$.

Berdasarkan data dari Dinas Kesehatan Kabupaten Karawang 2012, lebih dari separuh Puskesmas cakupannya masih kurang dari 72\%, sedangkan Provinsi DIY Cakupan K1 tahun 2011 99,98\% dan cakupan K1 di Kota Yogyakarta $100 \%$. Bila dibandingkan dengan cakupan $\mathrm{K} 1$ dari beberapa negara berkembang lainnya, cakupan $\mathrm{K} 1 \mathrm{di}$ Karawang masih lebih baik dari cakupan K1 di India yang hanya 58,76\% (Neha \& Mehta, 2015) dan cakupan K1 di Ghana 61,2\% (Asundep et al., 2014).

Berdasarkan data Riskesdas ketika ANC K1, ibu yang mendapatkan pemeriksaan lengkap (5T) di Provinsi Jawa Barat hanya $17,5 \%$, sedangkan di Provinsi DIY mencapai 40,5\% (Kementerian Kesehatan, 2010). Hasil FGD pada ibu hamil dan ibu menyusui di
Kabupaten Karawang, kebanyakan dari mereka mengatakan kalau bidan melakukan pemeriksaan berat badan, tensi dan periksa perut.

Hal ini sesuai dengan hasil wawancara dengan bidan senior di Karawang. Beliau mengatakan dengan tersenyum bahwa beliau tidak melakukan pemeriksaan secara lengkap, karena terlalu lama, yang pasti dilakukan hanya menimbang dan mengukur tensi sambil menanyakan keluhan ibu hamil.

Menurut Dinkes Kabupaten Karawang, masih cukup banyak bidan yang kurang pro aktif dan tidak memahami dengan baik juknis pelayanan ANC dan lebih bersifat menjalankan tugas rutin dengan menunggu pasien saja walaupun sudah dilakukan peningkatan kompetensi ANC, tetapi dirasakan belum efektif menunjukkan peningkatan.

Sebaliknya, ibu-ibu di Yogyakarta mengatakan bahwa mereka mendapatkan pemeriksaan lengkap. Karena selain pemeriksaan rutin oleh bidan mereka juga dikonsulkan untuk pemeriksaan gigi, konsultasi gizi, dan konsultasi psikologi.

Pernyataan yang sama dari bidan bahwa pemeriksaan ANC secara rinci sesuai dengan prosedur yang ditetapkan (head to toe). Hal ini dipertegas dengan pernyataan Kasie Kesga Sudinkes Kota Yogyakarta adanya PERWALI (peraturan wali kota) yang mengatur ANC terpadu yaitu $\mathrm{K} 1$ ibu hamil dilakukan pemeriksaan ANC ditambah dengan pemeriksaan gigi, gizi, dan laboratorium (urin).

Hasil dari kualitatif tersebut sesuai dengan hasil Riskesdas mengenai jenis pemeriksaan ketika ANC (Kementerian Kesehatan, 2010). Di negara-negara berkembang lainnya, ANC juga masih belum diterapkan dengan baik, seperti studi di tiga negara di Afrika yaitu Kenya, Malawi, dan Nigeria. Banyak ibu hamil datang ANC tidak menerima komponen penting pemeriksaan (Babalola, 2014).

Pemberian tablet tambah darah (TTD), masih banyak ibu di Provinsi Jawa Barat 
yang minum tablet Fe kurang dari 90 hari $(61,9 \%)$ (Kementerian Kesehatan, 2010). Hal ini diperkuat oleh studi kualitatif yaitu sebagian informanmengaku jarang/ tidak mengonsumsi tablet Fe secara teratur karena mual dan tidak ada penjelasan dari bidan mengenai manfaat TTD.

Pada Provinsi DIY, banyak ibu hamil yang mengonsumsi TTD lebih dari 90 tablet dan bidan juga menjelaskan peran komunitas dengan adanya kader pendamping ibu hamil dan suami siaga yang selalu mengingatkan ibu hamil untuk minum TTD secara teratur dan rajin ANC. Untuk meyakinkan ibu hamil mengerjakan petunjuk bidan, maka bidan meminta ibu hamil untuk mengulangi pesan yang sudah dijelaskan dan melakukan tes ulang $\mathrm{Hb}$ (apabila ibu hamil anemia).

Ketika melihat data tenaga kesehatan yang melakukan ANC, di Provinsi Jawa Barat masih ada ibu yang periksa kehamilannya ke dukun saja $(2,4 \%)$ atau ke dukun dan tenaga kesehatan $(10,5 \%)$ bahkan ada ibu yang tidak periksa kehamilan (1,3\%). Sebaliknya, di Provinsi DIY sudah tidak ada lagi ibu yang periksa ke dukun dan semua ibu memeriksakan kehamilannya ke tenaga kesehatan, walaupun ada $2 \%$ ibu yang melakukan pemeriksaan ke dukun juga selain ke tenaga kesehatan (Kementerian Kesehatan, 2010).

Hal ini dipertegas dengan hasil indepth interview dengan bidan di Kota Yogyakarta atau dengan Kasie KIA Dinas Kesehatan Yogyakarta. Hasil tersebut dikatakan bahwa di Kota Yogyakarta sudah tidak ada lagi ibu yang melahirkan dengan dukun dan sudah tidak ada tenaga dukun di sana.

Di sisi lain pada Provinsi DIY hampir sepertiga ibu (32,4\%) memeriksakan kehamilannya pada dokter spesialis kandungan, sedangkan di Jawa Barat hanya $18,7 \%$ ibu yang ANC dengan dokter spesialis kebidanan.Data ini diperkuat dengan hasil FGD (Focus Group
Disscusion) pada ibu hamil dan ibu menyusui.

Pada Kabupaten Karawang semua responden memeriksakan kehamilannya pada bidan baik di Posyandu, di Puskesmas atau pada bidan praktik. Begitu pula dengan Kota Yogyakarta banyak ibu yang mengatakan bahwa mereka memeriksakan kehamilan ke dokter spesialis kandungan, atau diperiksakan double ke spesialis kandungan dan ke bidan.

Penolong persalinan yang terampil adalah kunci utama melindungi kesehatan ibu dan bayi baru lahir (Gebre, Gebremariam and Abebe, 2015; Creanga et al., 2016) karena sebagian besar kematian perinatal terjadi selama persalinan dan melahirkan atau dalam 48 jam pertama setelahnya. Hal ini tenaga penolong kelahiran dapat mencegah sepertiga kematian ibu (Creanga et al., 2016).

Kematian ibu di negara berkembang 15 kali lebih tinggi daripada di negara maju. Sebagian besar kematian ibu karena tidak adanya akses ke perawatan rutin dan darurat terampil (Bitew et al., 2016). Etiopia termasuk salah satu negara di Afrika dengan kematian ibu yang tinggi (Berhan \& Berhan, 2014). Untuk Indonesia, Provinsi Jawa Barat menduduki peringkat tertinggi dalam jumlah AKI, penyumbang 50\% jumlah kematian ibu, yaitu sekitar 765 kasus dari total 5.019 kasus kematian ibu pada tahun 2014.

Waktu mulai ANC pertama, jumlah total kunjungan ANC yang diterima ibu hamil dan tidak memeriksa kehamilan pada layanan dapat menyebabkan dampak buruk pada bayi yang dilahirkan (Raatikainen et al., 2007). Hasil penelitian kohort pada ibu hamil di Tigray, Bagian Utara Ethiopiatahun 2017 didapatkan komplikasi perdarahan postpartum berkurang sebesar $81,2 \%$, kematian dini neonatal berkurang $61,3 \%$ dan BBLR berkurang $46,5 \%$ pada ibu hamil yang teratur melakukan ANC (Haftu et al., 2018). 
Penggunaan layanan perawatan kesehatan intensif mengurangi komplikasi kesehatan. Studi di India melaporkan ada hubungan yang signifikan wanita yang menerima perawatan antenatal penuh selama kehamilan lebih sedikit mengalami komplikasi selama persalinan dan periode pasca-melahirkan. (Gogoi et al., 2014).

Bila melihat pola ANC dengan pola 1,1,2, capaian di Provinsi DIY lebih tinggi dibandingkan dengan capaian di Jawa Barat. Hal ini diperkuat oleh pernyataan ibu hamil dan bidan di kota Yogyakarta bahwa rata-rata ANC ibu hamil 15 kali atau lebih. Ibu hamil menjelaskan dalam sebulan minimal mereka dua kali kontrol. Hal berbeda dijumpai di kabupaten Karawang, frekuensi ANC-nya lebih sedikit.

Di negara sub-Sahara Afrika dilaporkan sekitar $68 \%$ ibu hamil melakukan ANC setidaknya satu kali dan mayoritas dari mereka mengunjungi layanan kesehatan pada trimester ke ketiga. Data di Nepal, Pakistan, Bangladesh dan India, ibu hamil hanya sekali melakukan ANC dengan persentase berturut-turut 28\%, 28\%, 33\%, 60\% (Campbell \& Graham, 2006).

Ada banyak faktor lain yang mempengaruhi angka kematian ibu. Faktorlain yang mempengaruhi angka kematian ibu, di antaranya faktor sosio ekonomi, pendidikan ibu, kurang gizi, kurang pengetahuan tentang pencegahan infeksi, tinggal di daerah dengan akses layanan kesehatan yang terbatas sehingga lebih banyak yang mengalami komplikasi selama kehamilan dan persalinan.

Di Ghana, ibu yang tidak sekolah mengalami gejala pre-eklampsia secara signifikan lebih tinggi. Penjelasan yang mungkin adalah perempuan berpendidikan lebih mengetahui dengan baik prosedur ANC sehingga ketika melakukan kunjungan antenatal mereka akan lebih mungkin untuk meminta prosedur ANC yang lengkap (Babalola, 2014).
Pada studi Riskesdas terlihat bahwa responden di Provinsi Jawa Barat lebih banyak yang tidak bekerja, berpendidikan rendah dan punya anak $\geq 3$ bila dibandingkan dengan responden di Provinsi DIY. Artinya, status ekonomi dan pendidikan ibu di DIY lebih baik dibandingkan dengan ibu di Jawa Barat (Kementerian Kesehatan, 2010). Tantangan yang dihadapi Kabupaten Karawang untuk meningkatkan layanan ANC di antaranya rendahnya tingkat pendidikan masyarakat serta faktor budaya.

Berdasarkan hasil studi data SDKI 2002 dan 2007 mengenai kurangnya pemanfaatan layanan ANC diketahui karena beberapa faktor, yaitu wilayah dan tempat tinggal, sosio ekonomi status, pendidikan ibu, paritas, interval kelahiran, jarak ke fasilitas kesehatan, kurang terpapar media massa, dan tidak ada komplikasi obstetrik selama kehamilan.

Sebanyak 55\% dari total risiko kurang dimanfaatkannya layanan perawatan antenatal. Hal tersebut disebabkan oleh faktor kemiskinan dan tingkat pendidikan ibu yang rendah (Titaley et al., 2010). Memberi tahu tanda-tanda bahaya kehamilan merupakan hal penting yang harus disampaikan oleh petugas kesehatan pada waktu melakukan ANC. Berdasarkan data Riskesdas 2010, masih banyak ibu tidak diberitahu tanda bahaya kehamilan (Jawa Barat 56,2\%, DIY 41,6\%).

Pada penelitian di Uganda, hanya sekitar 1 dari 3 wanita yang mampu menyebutkan setidaknya tiga dari lima komponen dasar persiapan kelahiran dan kesiapsiagaan komplikasi $(\mathrm{BPCR}=$ the birth-preparedness and complication readiness). Konsep BPCR meliputi pengetahuan tentang tanda bahaya, perencanaan penolong persalinan dan lokasi persalinan, pengaturan transportasi, mengidentifikasi donor darah, dan menyimpan uang jika terjadi komplikasi kebidanan.

Seperempat ibu tidak bisa menyebutkan salah satu dari lima 
komponen tersebut (Mbalinda et al., 2014). Studi di Bagian Barat Laut Ethiopia, mayoritas $(71,8 \%)$ ibu hamil melakukan ANC di tingkat fasilitas Kesehatan, tetapi tidak semua menerima informasi tentang BPCR (Bitew et al., 2016).

Cakupan deteksi risiko oleh masyarakat di Kota Yogyakarta sangat tinggi yaitu mencapai 157,88\%. Oleh karena itu, walaupun didapatkan persentase ibu dengan komplikasi kehamilan yang lebih tinggi di Provinsi DIY dibandingkan dengan di Provinsi Jawa Barat, penanganannya lebih baik dan terencana sehingga angka kematian ibu hamilnya sangat rendah.

Komplikasi kehamilan yang menyebabkan kematian ibu dan kematian bayi dapat dicegah dengan mendeteksi dan mengobati komplikasi dari awal ketika ANC mulai dari proses kehamilan sampai saat melahirkan (Banda, 2012). Faktor yang mempengaruhi kematian ibu adalah tiga tingkat hambatan untuk perawatan kebidanan yang dikenal dengan 3-penundaan yaitu keterlambatan dalam keputusan untuk mencari perawatan, keterlambatan kedatangan di fasilitas Kesehatan, dan keterlambatan dalam penyediaan perawatan yang memadai (Creanga et al., 2016).

Terlambat memeriksa kehamilan pada kunjungan pertama ANC dapat menyebabkan tidak terdeteksi atau terlambatnya deteksi masalah kesehatan ibu yang menyebabkan komplikasi yang tidak tertangani yang berkontribusi pada kematian ibu. Studi di Ethiopia Selatan, sekitar tiga puluh persen wanita hamil yang melakukan kunjungan ANC pertama pada empat bulan kehamilan, degan durasi rata-rata ANC pertama adalah 5 bulan $( \pm 1,5)$ (Gebremeskel et al., 2015).

Penelitian di Ethiopia Selatan juga menunjukkan tingginya prevalensi keterlambatanpelayanan antenatal yaitu sebesar $68,6 \%$ dengan waktu rata-rata

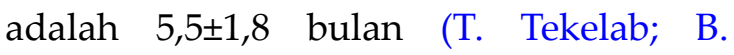
Berhanu, 2014). Berdasarkan Riskesdas
2010, cakupan ibu hamil yang melakukan K1 pada usia kehamilan 4 bulan ke atas pada Provinsi Jawa Barat dan DIY adalah $12,8 \%$ dan $6,9 \%$, cakupan ini menurun menjadi 11,3\% dan 5,6\% pada tahun 2018 .

Berdasarkan studi di Ethiopia Selatan mengenai faktor-faktor yang berhubungan dengan keterlambatan datang pada pelayanan antenatal pertama adalah pendapatan bulanan yang rendah, menerima saran tentang kapan memulai kunjungan ANC, kerawanan pangan rumah tangga, dan kehamilan yang tidak direncanakan (Gebremeskel et al., 2015).

Upaya percepatan penurunan angka kematian ibu (AKI) dapat tercapai bila setiap ibu hamil dapat mengakses pelayanan kesehatan yang berkualitas termasuk di dalamnya ANC yang teratur, pertolongan persalinan oleh tenaga kesehatan terlatih di faskes, perawatan pasca persalinan bagi ibu dan bayi, perawatan khusus dan rujukan jika terjadi komplikasi, dan pelayanan keluarga berencana termasuk KB pasca persalinan.

Asuhan antenatal harus menekankan pada kesiapsiagaan kelahiran dan kesiapan komplikasi $(\mathrm{BPCR}=$ the birthpreparedness

and complication readiness) untuk meningkatkan akses ke perawatan obstetri terampil dan darurat yang terbukti penting mengurangi mortalitas dan morbiditas ibu dan perinatal (Gebre et al., 2015).

\section{PENUTUP}

Rendahnya angka kematian ibu di Provinsi D.I. Yogyakarta, selain karena sudah baiknya penerapan ANC, disebabkan pula oleh adanya dukungan dari stakeholder. Memberitahu tanda bahaya kehamilan ketika ANC dan mendeteksi sejak awal kehamilan berisiko merupakan hal penting untuk mencegah terjadinya komplikasi kehamilan.

Selain itu, peran kader pendamping ibu hamil dan suami siaga sangat membantu dalam mencegah menurunkan 
angka kematian ibu di Yogyakarta dengan melakukan deteksi risiko komplikasi sejak awal. Upaya percepatan penurunan AKI dapat dilakukan dengan memastikan setiap ibu mampu mengakses pelayanan kesehatan ibu yang berkualitas.

\section{UCAPAN TERIMA KASIH}

Penulis mengucapkan terima kasih kepada Kepala Dinas dan staf Kabupaten Karawang dan Kota Yogyakarta, juga kepada bidan Puskesmas di kedua wilayah tersebut yang sangat membantu dalam memberikan informasi untuk memperkaya studi ini.

\section{DAFTAR PUSTAKA}

Alkema, L., Chou, D., Hogan, D., Zhang, S., Moller, A.-B., Gemmill, A., Fat, D. M., Boema, T., \& Temmerman, M. (2016). National, regional and global levels and trend in MMR between 1990 and 2015. The Lancet, 387(10017), 462-474. https://doi.org/10.1016/ S0140-6736(15)00838-7.National

Asundep, N. N., Jolly, P. E., Carson, A., Turpin, C. A., Zhang, K., \& Tameru, B. (2014). Antenatal care attendance, a surrogate for pregnancy outcome the case of kumasi, Ghana. Maternal and Child Health Journal, 18(5), 1085-1094. https://doi.org/10.1007/s10995-0131338-2

Babalola, S. (2014). Women's Education Level, Antenatal Visits and the Quality of Skilled Antenatal Care: A Study of Th ree African Countries. Journal of Health Care for the Poor and Undeserved, 25(1), 161-179.

Banda, I. (2012). Factors associated with late antenatal care attendance in selected rural and urban communities of the copperbelt province,Zambia. Medical Journal of Zambia, 39(3), 29-36.

Berhan, Y., \& Berhan, A. (2014). Review of maternal mortality in Ethiopia: a story of the past 30 years. Ethiopian Journal of Health Sciences, 24, 3-14. https:// doi.org/10.4314/ejhs.v24i0.2S
Bitew, Y., Awoke, W., \& Chekol, S. (2016). Birth Preparedness and Complication Readiness Practice and Associated Factors among Pregnant Women ,Northwest Ethiopia. International Scholarly Research Notices, 2016, 1-8. $\quad$ https://doi.org/ $10.1155 / 2016 / 8727365$

Campbell, O. M., \& Graham, W. J. (2006). Strategies for reducing maternal mortality: getting on with what works. Lancet, 368(9543), 1284-1299. https://doi.org/10.1016/S01406736(06)69381-1

Creanga, A. A., Odhiambo, G. A., Odera, B., Odhiambo, O., Desai, M., Goodwin, M., Laserson, K., \& Goldberg, H. (2016). Pregnant Women's Intentions and Subsequent Behaviors Regarding Maternal and Neonatal Service Utilization: Results from a Cohort Study in Nyanza Province, Kenya. PLoS ONE, 1-18. https://doi.org/10.1371/ journal.pone.0162017

Gebre, M., Gebremariam, A., \& Abebe, T. A. (2015). Birth Preparedness and Complication Readiness among Pregnant Women in Duguna Fango District, Wolayta Zone,. 103, 1-13. https:// doi.org/10.1371/journal.pone.0137570

Gebremeskel, F., Dibaba, Y., \& Admassu, B. (2015). Timing of First Antenatal Care Attendance and Associated Factors among Pregnant Women in Arba Minch Town and Arba Minch District, Gamo Gofa Zone , South Ethiopia. Journal of Environmental and Public Health, 2015, 1-7. https://doi.org/ 10.1155/2015/971506

Gogoi, M., Unisa, S., \& Prusty, R. K. (2014). Utilization of maternal health care services and reproductive health complications in Assam, India. Journal of Public Health (Germany), 22(4), 351359. https://doi.org/10.1007/s10389014-0614-y

Haftu, A., Hagos, H., Mehari, M. A., \& Gher, B. (2018). Pregnant women 
adherence level to antenatal care visit and its effect on perinatal outcome among mothers in Tigray Public Health institutions, 2017: Cohort study 11 Medical and Health Sciences 1114 Paediatrics and Reproductive Medicine 11 Medical and Heal. BMC Research Notes, 11(1), 1-6. https:// doi.org/10.1186/s13104-018-3987-0

Kementerian Kesehatan. (2010). Riset Kesehatan Dasar 2010. In Badan Penelitian dan Pengembangan Kesehatan.

Kementerian Kesehatan. (2014). Situasi Kesehatan Ibu. Info Datin, Pusat Data dan Informasi.

Kementerian Kesehatan. (2019). Laporan Nasional Riskedas 2018.

Mbalinda, S. N., Nakimuli, A., Kakaire, O., Osinde, M. O., Kakande, N., \& Kaye, D. K. (2014). Does knowledge of danger signs of pregnancy predict birth preparedness? A critique of the evidence from women admitted with pregnancy complications. Health Research Policy and Systems, 12(1), 1-7. https://doi.org/10.1186/1478-4505-1260

Neha, \& Mehta. (2015). A Study on Quality Assessment of Antenatal Care Given at Anganwadi Centers of Jamnagar Municipal Corporation Area. Indian Journal of Preventive Medicine, 3(1), 1521.

Raatikainen, K., Heiskanen, N., \& Heinonen, S. (2007). Under-attending free antenatal care is associated with adverse pregnancy outcomes. BMC Public Health, 7, 1-8. https://doi.org/ 10.1186/1471-2458-7-268

Say, L., Chou, D., Gemmill, A., Tunçalp, Ö., Moller, A. B., Daniels, J., Gülmezoglu, A. M., Temmerman, M., \& Alkema, L. (2014). Global causes of maternal death: A WHO systematic analysis. The Lancet Global Health, 2(6), 1-11. https://doi.org/10.1016/S2214109X(14)70227-X

Susiana S. (2019). Angka kematian ibu: Faktor penyebab dan upaya penanganannya. Kajian singkat terhadap isu actual dan strategis. Info Singkat, Vol. XI, N.

T. Tekelab; B. Berhanu. (2014). Factors Associated with Late Initiation of Antenatal Care among Pregnant Women Attending Antenatal Clinic at Public Health Centers in Kembata Tembaro Zone, Southern Ethiopia. 7522(Jan-April), 108115.

Titaley, C. R., Dibley, M. J., \& Roberts, C. L. (2010). Factors associated with underutilization of antenatal care services in Indonesia: Results of Indonesia Demographic and Health Survey 2002/2003 and 2007. BMC Public Health, 10. https://doi.org/ 10.1186/1471-2458-10-485

WHO. (2019). Maternal mortality. September, 1-5. 